\title{
Prognostic value of HPV-mRNA in sentinel Iymph nodes of cervical cancer patients with pNO-status
}

\author{
Matthias Dürst ${ }^{1}$, Heike Hoyer ${ }^{2}$, Christoph Altgassen ${ }^{3}$, Christiane Greinke ${ }^{1}$, Norman \\ Häfner ${ }^{1}$, Alba Fishta ${ }^{1}$, Mieczyslaw Gajda ${ }^{4}$, Ute Mahnert ${ }^{5}$, Peter Hillemanns ${ }^{6}$, \\ Thomas Dimpfl', Miriam Lenhard ${ }^{8}$, K. Ulrich Petry ${ }^{9}$, Ingo B. Runnebaum ${ }^{1}$ and \\ Achim Schneider ${ }^{10}$ \\ ${ }^{1}$ Department of Gynecology, Jena University Hospital, Friedrich-Schiller-University, Jena, Germany \\ 2 Institute of Medical Statistics, Information Sciences and Documentation, Jena University Hospital, Friedrich-Schiller- \\ University, Jena, Germany \\ ${ }^{3}$ Department of Gynecology and Obstetrics, Universitätsklinikum Schleswig-Holstein, Lübeck, Germany \\ ${ }^{4}$ Institute of Pathology, Jena University Hospital, Friedrich-Schiller-University, Jena, Germany \\ ${ }^{5}$ Department of Gynecology and Obstetrics, Helios Klinikum Erfurt GmbH, Erfurt, Germany \\ ${ }^{6}$ Department of Gynecology and Obstetrics, Medizinische Hochschule Hannover, Hannover, Germany \\ 7 Department of Gynecology and Obstetrics, Klinikum Kassel GmbH, Kassel, Germany \\ ${ }^{8}$ Department of Gynecology and Obstetrics, Ludwig-Maximilians-University Munich, Campus Grosshadern, Munich, Germany \\ ${ }^{9}$ Department of Gynecology and Obstetrics, Klinikum Wolfsburg, Wolfsburg, Germany \\ ${ }^{10}$ Institute for Cytology and Dysplasia, Fürstenbergkarree, Berlin, Germany \\ Correspondence to: Matthias Dürst, email: matthias.duerst@med.uni-jena.de \\ Keywords: sentinel lymph node, cervical cancer, HPV-mRNA, prognosis, disease free survival \\ Received: April 15, $2015 \quad$ Accepted: April 20, $2015 \quad$ Published: May 14, 2015
}

This is an open-access article distributed under the terms of the Creative Commons Attribution License, which permits unrestricted use, distribution, and reproduction in any medium, provided the original author and source are credited.

\section{ABSTRACT}

Up to $15 \%$ of patients with cervical cancer and pN0-status develop recurrentdisease. This may be due to occult metastatic spread of tumor cells. We evaluated the use of human-papillomavirus-(HPV)-mRNA as a molecular marker for disseminated tumor cells to predict the risk of recurrence. For this prospective, multi-center prognostic study, 189 patients free of lymphnode metastases by conventional histopathology could be analyzed. All patients underwent complete lymphadenectomy. Of each sentinel node (SLN) a biopsy was taken for the detection of HPV-E6-E7-mRNA. Median follow-up time after surgery was 8.1 years. HPV-mRNA could be detected in SLN of 52 patients ( $27.5 \%)$. Recurrence was observed in 22 patients. Recurrencefree-survival was significantly longer for patients with HPV-negative SLN (log rank $p$ $=0.002)$. By Cox regression analysis the hazard ratio $(95 \% \mathrm{CI})$ for disease-recurrence was $3.8(1.5-9.3, p=0.004)$ for HPV-mRNA-positive compared to HPV-mRNAnegative patients. After adjustment for tumor size as the most influential covariate the HR was still $2.8(1.1-7.0, p=0.030)$. In patients with cervical cancer and tumorfree lymph nodes by conventional histopathology HPV-mRNA-positive SLN were of prognostic value independent of tumor size. Particularly, patients with tumors larger than $20 \mathrm{~mm}$ diameter could possibly benefit from further risk stratification using HPVmRNA as a molecular marker.

\section{INTRODUCTION}

In patients with cervical cancer, metastatic spread to lymph nodes is known to be the most important prognostic parameter which is crucial for selection of therapy. The risk of lymph node metastases in women with early stage cervical cancer (up to FIGO stage IB1) is approximately $15 \%$ and as a consequence the majority 
of patients do not benefit from lymphadenectomy [1, 2]. Radical lymphadenectomy leads to lymphedema, serocele formation, paresthesia, voiding disorders, and possibly reduced immune competence. In recent years the use of sentinel lymph node biopsy (SLN) was explored extensively. The concept is based on the assumption that if the first draining lymph node is free of disease, all other lymph nodes in the nodal basin should also be free of disease [3]. An initial study examining the utility of SLN biopsy in patients diagnosed with cervical cancer showed great promise with a detection rate, sensitivity and negative predictive value of $94 \%, 90.9 \%$ and $99.1 \%$, respectively for patients with tumors measuring $2 \mathrm{~cm}$ or less in diameter [4]. In more recent studies it was shown that sensitivity was close to $100 \%$ in patients where SLNs were detected bilaterally [5-7]. Moreover, the detection of nodal metastasis was improved by ultrastaging which comprises multiple serial sectioning and immunohistochemical staining of the SLN $[6,7]$. Indeed, there is even a report that sentinel lymph node biopsy in early stage cancer is a more sensitive procedure in detecting pelvic lymph node metastases compared to complete lymphadenectomy [8]. Ultrastaging allows the detection of low-volume disease which includes micrometastasis (MM) and isolated tumor cells (ITC). By definition, macrometastasis are tumor deposits $>2 \mathrm{~mm}$, micrometastasis are deposits between $>0.2$ and $2 \mathrm{~mm}$, and ITC are deposits $\leq 0.2 \mathrm{~mm}$ including the presence of single non-cohesive cytokeratin-positive tumor cells [9]. However, the prognostic implications of low volume metastatic disease (micrometastasis and ITC) for patients with cervical cancer are not yet fully understood and serve only partly as prognostic indicators $[6,10]$.

The identification of ITC, in particular single tumor cells, requires a highly specific marker. In this context, the detection of cytokeratins by immunohistochemical staining or at the mRNA level is not ideal $[11,12]$. Moreover, in a recent study it was shown that benign epithelial cells can be displaced iatrogenetically and transported to sentinel lymph nodes [13]. Thus, in order to address the clinical significance of small numbers of tumor cells in SLN, it is mandatory to use the most specific markers available. Characteristic of all cervical cancer cells is the presence of high-risk-(hr)HPV-DNA [14] and the constitutive expression of the viral oncogenes E6 and E7 [15]. In an earlier study we showed by quantitative reverse-transcription-PCR that HPV16-E6-E7-mRNA is more sensitive and more specific than cytokeratin-(CK)19mRNA for the detection of disseminated tumor cells in SLN [16]. The present study evaluates the prognostic value of hrHPV-E6-E7-mRNA in SLN biopsies of cervical cancer patients with pN0 status based on conventional histopathologic findings.

\section{RESULTS}

\section{Patients enrolled}

We enrolled 189 out of 338 eligible patients (Figure 1). Median age was 40 years and FIGO stages ranged from IA1 to IIB. Further details are given in Table 1. Key data of patients excluded are shown in Table 2. Except for histology there were no remarkable differences for age, tumor size and grading. During the follow-up period disease recurred in 22 patients (Figure 1), overall 15 patients died (Supplementary Table S2). The probabilities of recurrence free survival and overall survival five years after surgery were $90.1 \%$ (95\% CI 84.8 - 93.7\%) and $93.3 \%$ (95\% CI 88.2 - 96.2\%), respectively.

\section{HPV status in primary tumors and sentinel lymph nodes}

Close to $60 \%$ of the primary tumors were HPV 16 positive, $22 \%$ were HPV18 positive and the remaining tumors were either HPV35-, HPV45- or HPV73-positive. HPV-mRNA of the respective HPV type could be detected by RT-nested-PCR in SLN of 52 patients (27.5\%). 119 patients $(63 \%)$ had negative and 18 patients $(9.5 \%)$ had probably negative findings (Figure 1).

\section{Prognostic value of HPV-mRNA in sentinel lymph nodes}

In our primary analysis we included 171 patients with unequivocal HPV-mRNA findings as determined by RT-nested-PCR. Recurrence-free survival was significantly longer in patients with HPV-mRNA negative SLN (log rank $p=0.002)$. Five years after surgery $94.8 \%(95 \% \mathrm{CI}$ $88.8-97.6 \%)$ of these patients survived without relapse compared to $80.2 \%$ (95\% CI $66.2-88.8 \%)$ of patients with positive SLN (Figure $2 \mathrm{a}$ and Table 3 ). Results of the Cox-regression analysis are given in Table 4 . The hazard ratio (HR) for disease recurrence was 3.8 (95\% CI $1.5-$ 9.3, $p=0.004$ ) for HPV positive compared to patients with HPV-mRNA negative SNL. In single factor models tumor size was the most influential prognostic variable. Compared to patients with small tumors the risk of disease recurrence was 9 -fold and 20 -fold if tumor size was $>20$ to $40 \mathrm{~mm}$ and $>40 \mathrm{~mm}$, respectively. Grading and histology were not significantly associated with recurrence-free survival. The significant effect of HPV-mRNA in SLN was preserved in all two-factor Cox models. As expected from single factor models, the largest change in estimate was observed after inclusion of tumor size. HR for HPV positive compared to negative patients decreased to 2.8 $(95 \%$ CI $1.1-7.0, p=0.030)$. The independent prognostic 
Table 1: Characteristics of patients according to HPV mRNA status of sentinel lymph nodes $(n=189)$

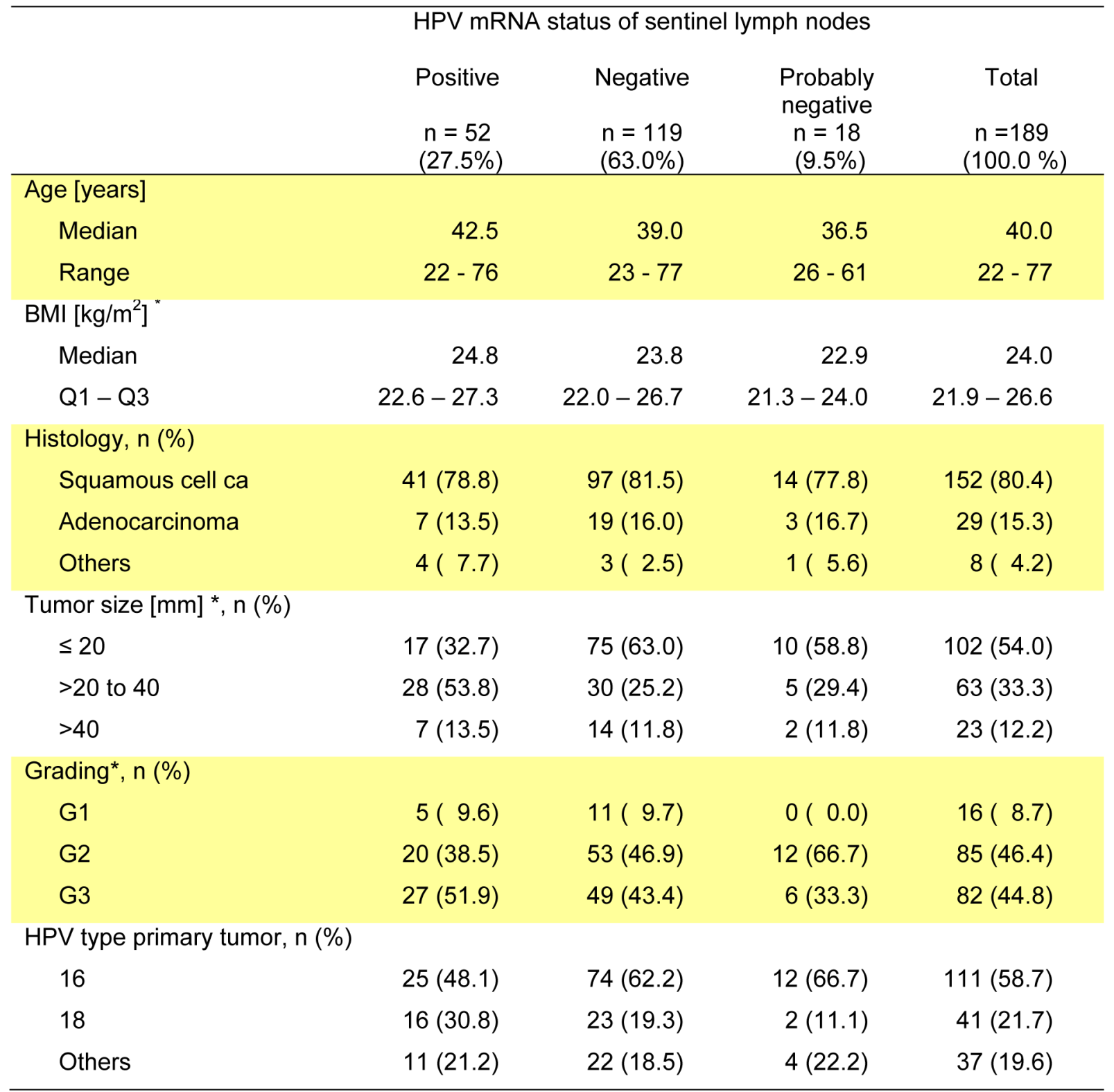

Abbreviations: BMI - body mass index, Q1 - first quartile, Q3 - third quartile, ca. - cancer

*Missing values BMI ( $n=39)$, tumor size $(n=1)$, grading $(n=6)$

values of tumor size and HPV-mRNA in SLN are shown in stratified Kaplan-Meier curves (Figure 2b). The benefit of HPV-mRNA as marker was obvious in patients with tumor size larger than $20 \mathrm{~mm}$ due to the higher risk of recurrence (Table 3).

In a sensitivity analysis we included all 189 patients assigning those with probably negative HPV-mRNA status to the HPV-mRNA negative group. For HPV-mRNA positive compared to negative patients a crude HR for disease recurrence of $3.4(95 \%$ CI $1.4-8.0, p=0.004)$ and a tumor size adjusted HR of 2.5 (95\% CI $1.0-6.0$, $p=0.034$ ) was estimated (Supplementary Table S4).

For Kaplan-Meier curves of recurrent free survival and five-years of recurrence free survival see Supplementary Figure S1 and Supplementary Table S3.

Post-hoc we analyzed the effect of HPV-mRNA in SLN on total mortality. In the primary analysis population $(n=171)$ the crude and tumor size adjusted HR was 2.8 $(95 \%$ CI $0.9-8.5, p=0.060)$ and 2.5 (95\%CI 0.8, 7.7, $p=0.113)$, respectively. The sensitivity analysis $(n=$ $189)$ revealed a crude $\mathrm{HR}$ of $2.5(95 \% \mathrm{CI} 0.8-6.7, p=$ 0.084 ) which decreased after tumor size adjustment to 2.1 $(95 \%$ CI $0.7-6.1, p=0.154)$. 
Table 2: Characteristic of study population compared to patients excluded from study

\begin{tabular}{lccc}
\hline & $\begin{array}{c}\text { Study } \\
\text { population } \\
(\mathrm{n}=189)\end{array}$ & $\begin{array}{c}\text { Patients not } \\
\text { included } \\
(\mathrm{n}=149)\end{array}$ & p-value \\
\hline Age [years] & 40 & 40 & $0.701^{*}$ \\
$\quad$ Median & $22-77$ & $20-73$ & \\
$\quad$ Range & & & $0.020^{* *}$ \\
Histology, $\mathrm{n}(\%)$ & $152(80.4)$ & $101(67.8)$ & \\
$\quad$ Squamous cell cancer & $29(15.3)$ & $41(27.5)$ & \\
Adenocarcinoma & $8(4.2)$ & $7(4.7)$ & $0.718^{* *}$ \\
Others & $102(54.3)$ & $83(56.1)$ & \\
Tumor size [mm], $\mathrm{n}(\%)$ & $63(33.5)$ & $44(29.7)$ & \\
$\leq 20$ & $23(12.3)$ & $21(14.2)$ & \\
$>20$ to 40 & 1 & 1 & $0.045^{* *}$ \\
$>40$ & & & \\
Missing & $16(8.7)$ & $4(2.8)$ & \\
Grading, $\mathrm{n}(\%)$ & $85(46.7)$ & $79(56.0)$ & \\
G1 & $82(44.8)$ & $58(41.1)$ & \\
G2 & 6 & 8 & \\
G3 & & & \\
Missing & & & \\
\hline
\end{tabular}

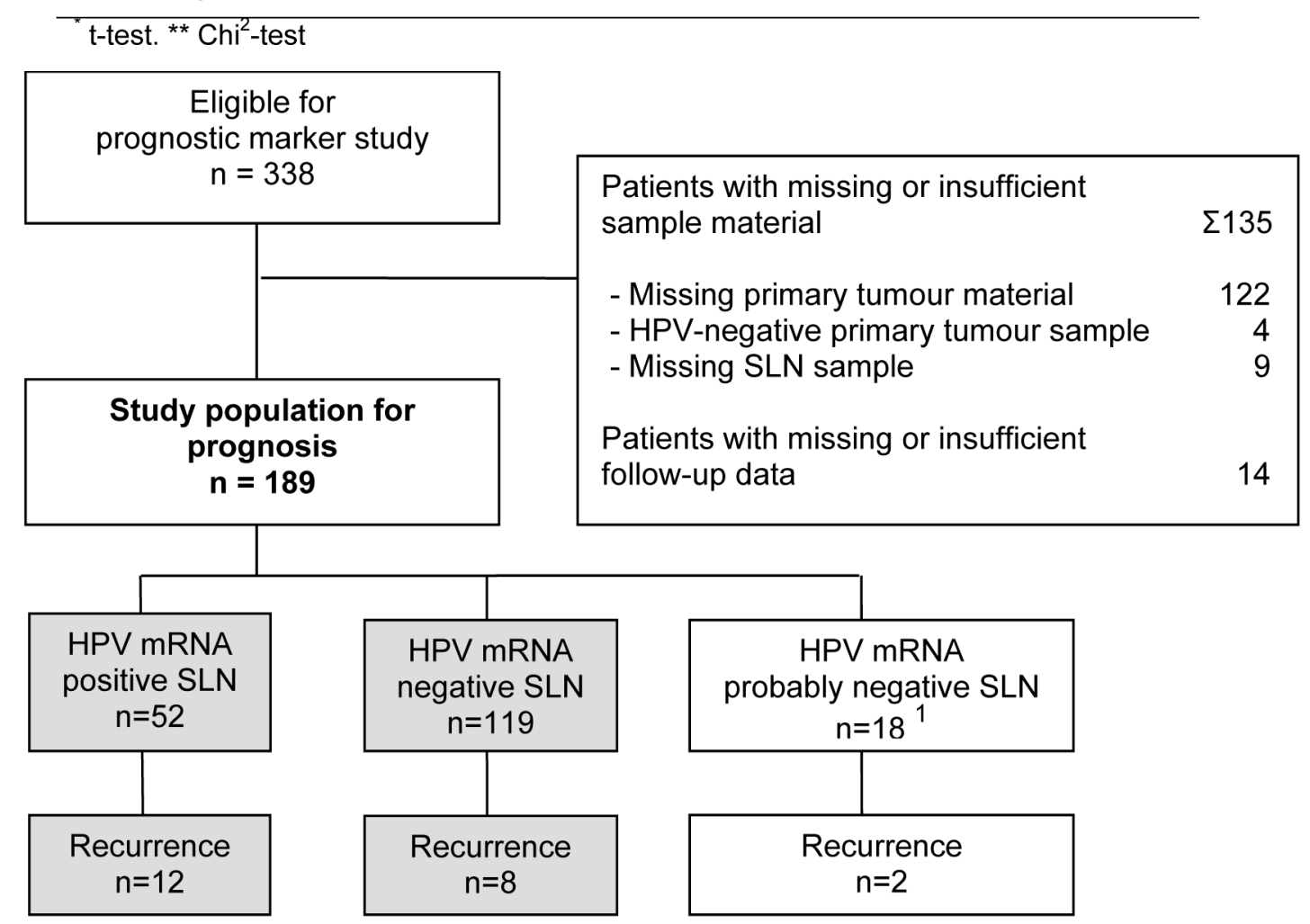

${ }^{1}$ Patients with negative but incomplete SLN evaluation; excluded from primary analysis; classified as HPV-mRNA negative for sensitivity analysis

Figure 1: Study flow. 
(a)

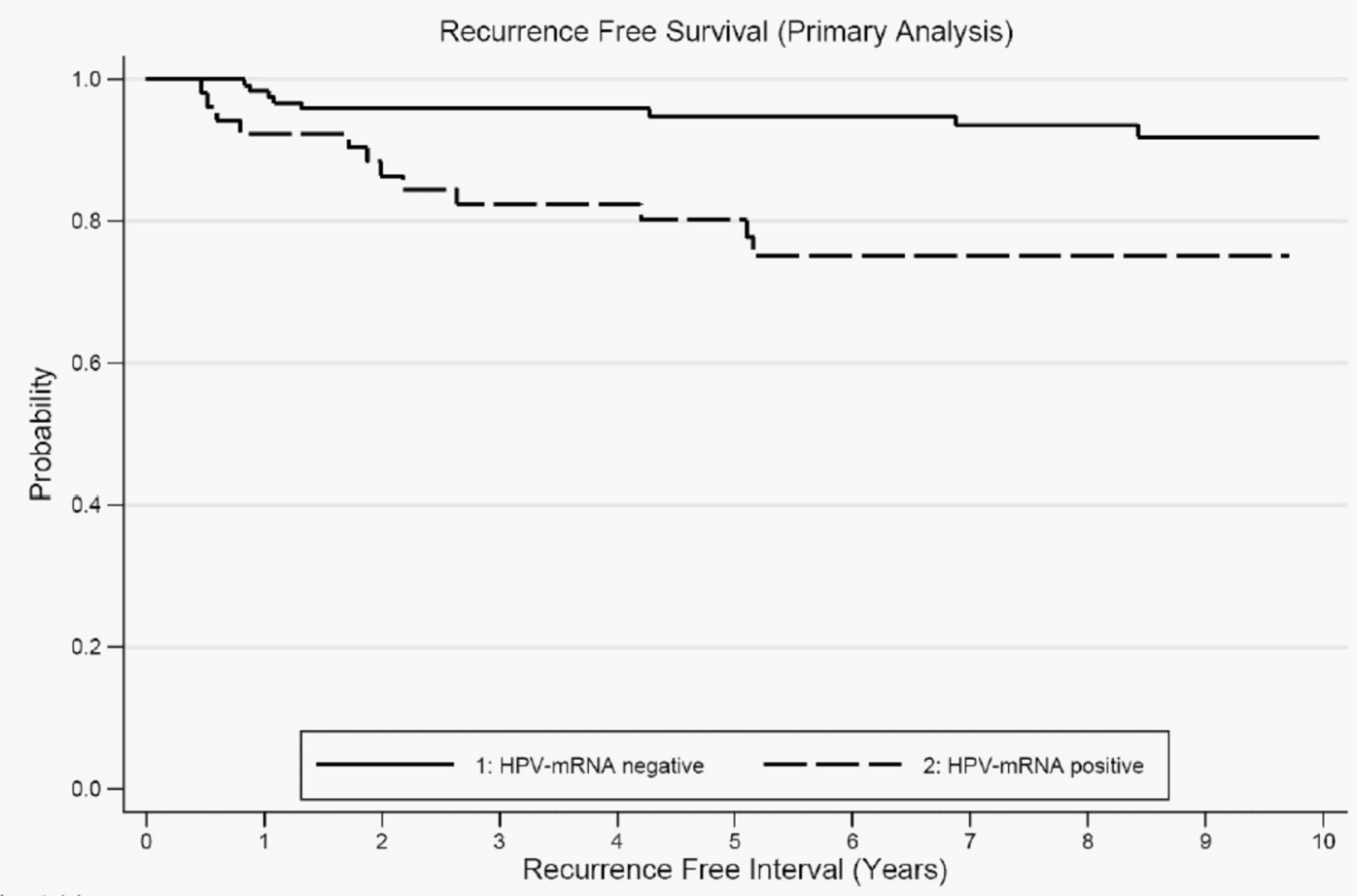

No. at risk

\begin{tabular}{|c|c|c|c|c|c|c|c|c|c|}
\hline 119 & 117 & 110 & 102 & 96 & 91 & 85 & 74 & 59 & 45 \\
\hline 52 & 47 & 44 & 41 & 37 & 34 & 28 & 27 & 24 & 18 \\
\hline
\end{tabular}

(b)

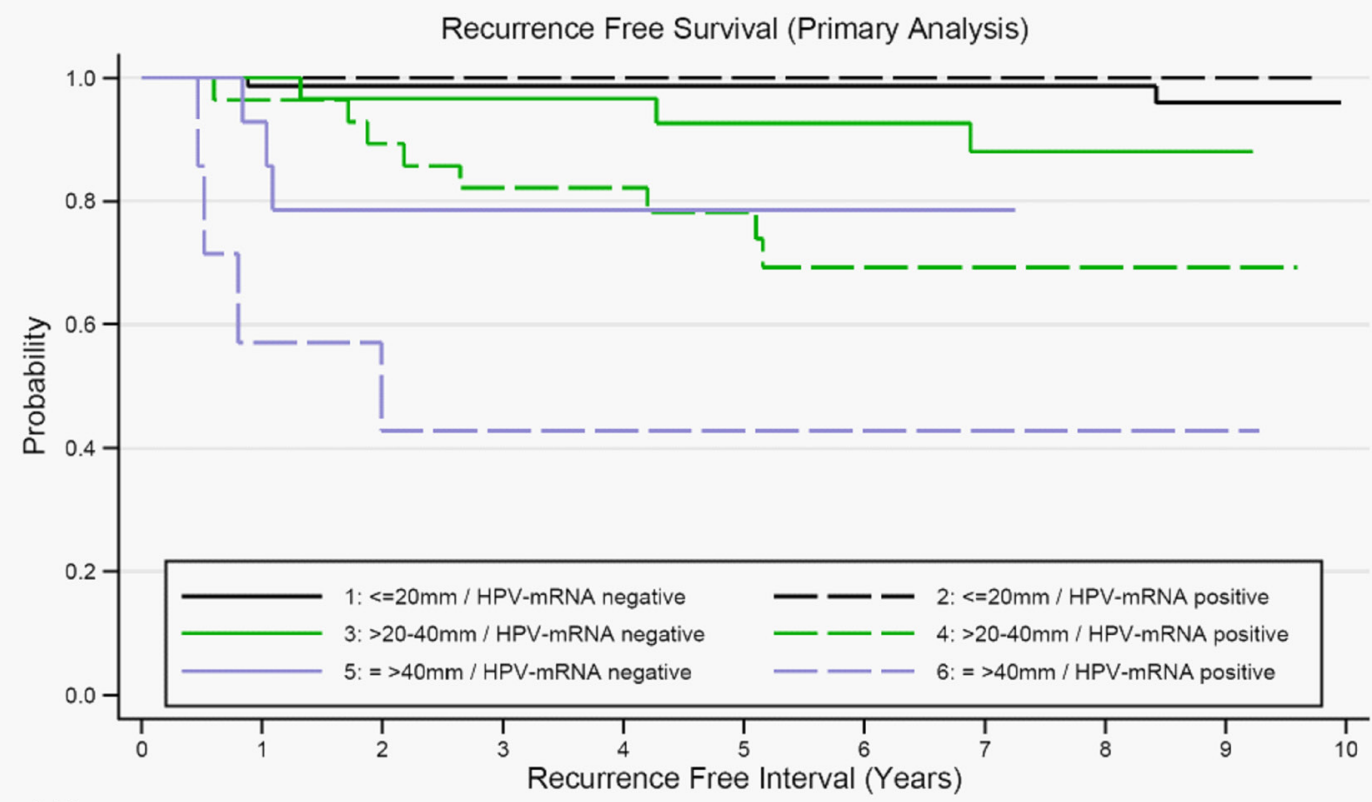

No. at risk

$\begin{array}{rrrrrrrrrrrr}\text { 1: } & 75 & 74 & 72 & 67 & 62 & 59 & 54 & 48 & 39 & 30 & 22 \\ \text { 2: } & 17 & 16 & 16 & 15 & 12 & 12 & 11 & 11 & 10 & 10 & 7 \\ \text { 3: } & 30 & 30 & 27 & 25 & 24 & 23 & 22 & 19 & 16 & 11 & 10 \\ \text { 4: } & 28 & 27 & 25 & 23 & 22 & 19 & 14 & 13 & 11 & 6 \\ \text { 5: } & 14 & 13 & 11 & 10 & 10 & 9 & 9 & 7 & 4 & 4 & 2 \\ \text { 6: } & 7 & 4 & 3 & 3 & 3 & 3 & 3 & 3 & 3 & 2 & 1\end{array}$

Figure 2: a. Kaplan-Meier curves of recurrence-free survival according to HPV-mRNA status of sentinel lymph nodes; log rank test $p$ $=0.002$ (primary analysis population $n=171$ ) and $\mathbf{b}$. Kaplan-Meier curves of recurrence-free survival according HPV-mRNA status of sentinel lymph nodes stratified by tumor size; log rank test for HPV-mRNA adjusted for tumor size $p=0.027$ (primary analysis population $n=171$ ). 
Table 3: Five-years rate of recurrence free survival according to HPV mRNA status of sentinel lymph nodes stratified by tumor size (primary analysis population, $\mathrm{n}=171$ )

\begin{tabular}{|c|c|c|c|}
\hline Tumor size [mm] & $\begin{array}{l}\text { HPV mRNA of } \\
\text { SLN }\end{array}$ & $\begin{array}{l}\text { Disease } \\
\text { recurrence }(n)\end{array}$ & $\begin{array}{c}\text { 5-years rate of } \\
\text { recurrence free survival }(95 \% \mathrm{Cl})\end{array}$ \\
\hline all & all & $20(171)$ & $90.3(84.6-93.9) \%$ \\
\hline \multirow[t]{2}{*}{ all } & negative & $8(119)$ & $94.8(88.8-97.6) \%$ \\
\hline & positive & $12(52)$ & $80.2(66.2-88.8) \%$ \\
\hline \multirow[t]{5}{*}{ ** } & negative & $2(75)$ & $98.7(90.9-99.8) \%$ \\
\hline & positive & $0(17)$ & 100.0 \\
\hline & negative & $3(30)$ & $92.6(73.5-98.1) \%$ \\
\hline & positive & $8(28)$ & $78.2(57.8-89.6) \%$ \\
\hline & negative & $3(14)$ & $78.6(47.2-92.5) \%$ \\
\hline & positive & $4(7)$ & $42.9(9.8-73.4) \%$ \\
\hline
\end{tabular}

Abbreviations: SLN - sentinel lymph node, $\mathrm{Cl}$ - confidence interval

* Log rank test for HPV mRNA: $p=0.002$

${ }^{* *}$ Log rank test for HPV mRNA adjusted for tumor size: $\mathrm{p}=0.027$

\section{Cancer-related recurrence and death according to HPV-mRNA status}

Recurrence of disease was observed in 22 patients of whom 16 experienced loco-regional recurrence and 6 patients were diagnosed with distant metastasis outside the pelvis or in liver, lungs or spleen. The interval between primary treatment and recurrence varied between 5 and 101 months with late recurrence in 2 patients after 4 years, 2 patients after 5 years and 2 patients after 6 or 8 years, respectively. Overall 15 patients died during follow up. Interestingly, among the HPV-mRNA positive group 6 out of 7 deaths were directly related to cancer. In contrast, this was only the case for 3 out of 8 deaths among the HPVmRNA negative group (Supplementary Table S2).

\section{DISCUSSION}

Multiple studies have shown that SLN mapping in patients with early stage cervical cancer is feasible with excellent detection rates and sensitivity. Especially ultrastaging allows the detection not only of macro- and micrometastasis but also of ITC [6, 23]. However, whereas detection of micrometastasis may have a prognostic impact, ITC were shown not to be of prognostic value [6]. It is also of note that for breast cancer there is a lack of consensus in the literature about the predictive value of ITC as determined by cytokeratin staining in terms of both disease-free survival and death from disease [24]. It needs to be considered that cytokeratin stained cells do not invariably represent tumor cells. Indeed, a lack of specificity of cytokeratin-staining at a single cell level was shown by Bleiweiss and colleagues [13]. Thus, rather than using epithelial markers we had chosen HPV-E6E7-mRNA as a molecular marker for the detection of tumor cells in SLN shown to be negative by conventional histopathology. HPV-DNA is less ideal as a marker because fragmented viral DNA may also be present in lymphocytes and would give rise to false-positive results [16].

This is the first multicenter prospective study which addresses the prognostic potential of HPVmRNA in SLN of patients with pN0-status by systematic lymphadenectomy and conventional histopathology. We could show that recurrence-free survival was significantly longer for patients with HPV-mRNA negative SLN (log rank $p=0.002$ ). By Cox-regression analysis the hazard ratio $(95 \%$ confidence interval) for disease recurrence was $3.8(1.5-9.3, p=0.004)$ for HPV-mRNA positive compared to negative patients. Most importantly, after adjustment for tumor size as the most influential covariate for recurrence, the hazard ratio was still 2.8 (1.1 - 7.0, $p$ $=0.030$ ).

Although RT-nested-PCR is extremely sensitive it is not a quantitative assay. Therefore, in order to estimate the HPV16-mRNA levels in SLN, we also analyzed 77 SLN of a subset of patients by qRT-PCR. By this approach one tumor cell $(\mathrm{SiHa})$ in a background of $10^{5} \mathrm{HPV}$-negative cells can be detected [16]. We could show that in SLN which were negative for micrometastasis by cytokeratin staining, one to $10^{2}$ HPV16-E6-E7 transcripts were detected in 50ng of total RNA (Supplementary Figure S2a). In terms of a tissue section this corresponds to single dispersed tumor cells. The agreement between the two different mRNA assays (qRT-PCR versus RT-nestedPCR) was high (kappa 0.8; Supplementary Figure S2b). As expected, the RT-nested-PCR approach was somewhat 
Table 4: Strength of association between prognostic factors and recurrence free survival determined by Cox regression analysis (primary analysis population, $\mathrm{n}=171$ )

\begin{tabular}{|c|c|c|c|c|}
\hline & & $\mathrm{n}$ & Hazard Ratio $(95 \% \mathrm{Cl})$ & $p$-value $e^{\star *}$ \\
\hline \multicolumn{5}{|l|}{ Single factor models } \\
\hline \multirow[t]{2}{*}{ HPV mRNA of SLN } & negative & 119 & 1 & 0.004 \\
\hline & positive & 52 & $3.79(1.54-9.27)$ & \\
\hline \multirow[t]{3}{*}{ Tumor size [mm] } & $\leq 20$ & 92 & 1 & $<0.001$ \\
\hline & $>20$ to 40 & 58 & $9.20(2.03-41.53)$ & \\
\hline & $>40$ & 21 & $19.68(4.08-94.80)$ & \\
\hline \multirow[t]{3}{*}{ Histology } & Squamous cell ca & 138 & 1 & 0.869 \\
\hline & Adenocarcinoma & 26 & $1.34(0.44-4.03)$ & \\
\hline & Others & 7 & $1.21(0.15-9.13)$ & \\
\hline \multirow[t]{3}{*}{ Grading* } & G1 & 16 & 1 & 0.096 \\
\hline & G2 & 73 & $0.29(0.06-1.29)$ & \\
\hline & G3 & 76 & $0.96(0.27-3.38)$ & \\
\hline Age [years] & & 171 & $1.03(1.00-1.07)$ & 0.050 \\
\hline \multicolumn{5}{|l|}{ Two factor models } \\
\hline \multirow[t]{2}{*}{ HPV mRNA of SLN } & negative & 119 & 1 & 0.030 \\
\hline & positive & 52 & $2.79(1.10-7.03)$ & \\
\hline \multirow[t]{3}{*}{ Tumor size } & $\leq 20 \mathrm{~mm}$ & 92 & 1 & 0.001 \\
\hline & $>20-40 \mathrm{~mm}$ & 58 & $6.66(1.43-30.99)$ & \\
\hline & $>40 \mathrm{~mm}$ & 21 & $17.77(3.67-85.93)$ & \\
\hline \multirow[t]{2}{*}{ HPV mRNA of SLN } & negative & 119 & 1 & 0.004 \\
\hline & positive & 52 & $3.81(1.55-9.38)$ & \\
\hline \multirow[t]{3}{*}{ Histology } & Squamous cell ca & 138 & 1 & 0.877 \\
\hline & Adenocarcinoma & 26 & $1.30(0.43-3.92)$ & \\
\hline & Others & 7 & $0.85(0.11-6.47)$ & \\
\hline \multirow[t]{2}{*}{ HPV mRNA of SLN* } & negative & 113 & 1 & 0.009 \\
\hline & positive & 52 & $3.29(1.34-8.08)$ & \\
\hline \multirow[t]{3}{*}{ Grading* } & $\mathrm{G} 1$ & 16 & 1 & 0.142 \\
\hline & G2 & 73 & $0.32(0.07-1.42)$ & \\
\hline & G3 & 76 & $0.95(0.27-3.35)$ & \\
\hline \multirow[t]{2}{*}{ HPV mRNA of SLN } & negative & 119 & 1 & 0.005 \\
\hline & positive & 52 & $3.63(1.48-8.89)$ & \\
\hline Age [years] & & 171 & $1.03(0.99-1.07)$ & 0.070 \\
\hline
\end{tabular}

Abbreviations: SLN - sentinel lymph node, $\mathrm{Cl}$ - confidence interval, ca. - cancer

* Valid datasets: Grading and related two factor model $n=165$

${ }^{* *}$ Wald test 
more sensitive.

There are several limitations of our study. First, a high percentage of eligible patients had to be excluded because of missing or insufficient sample material. To minimize the risk of contamination the study protocol required all samples to be taken as fresh frozen biopsies at the time of surgery. As shown in Table 2, patients excluded differed in histology $(p=0.02)$ and marginally in grading $(p=0.045)$. However, both characteristics did not influence recurrence-free survival in our study. Additionally, recurrence-free survival of the excluded subjects was similar at the regular end of the study (log rank test $p=0.42$ ). Second, the power of our statistical analysis was lower than assumed. Moreover, the initial follow-up period of 3 years for recurrent disease was too short and had to be prolonged. The final number of 22 patients with recurrence was still lower than expected. Therefore the number of simultaneous covariates in the Cox-regression model had to be restricted and may have resulted in incomplete control of confounding. Third, the HPV-mRNA status of SLN was unclear in eighteen patients. For these cases the SLN count by the surgeon did not match with the number counted by the pathologist. The SLN available for HPV-mRNA analyses however were negative. When we included the data of patients with equivocal results, the sensitivity analysis revealed a weaker but still significant association (Supplementary Figure S1 and Supplementary Tables S3 and S4). This approach was specified in the statistical analysis plan before the recurrence status became known to the principal investigator. Forth, the biopsy taken from SLN for mRNA analysis may not have been representative of the whole node. Tumor cell distribution can be inhomogeneous in lymph nodes [25]. Thus, an unknown number of SLN may be false-negative.

In conclusion, our data suggest that the presence of HPV-E6-E7-mRNA in SLN of patients with pN0 status was associated with a significantly decreased recurrencefree survival. For the detection of isolated tumors cells HPV-E6-E7-mRNA as a biomarker is of unmatched specificity [16]. The clinical implications of HPV-mRNA in SLN and the net benefit for the patients with respect to therapy options will have to be addressed in further studies. It is envisaged that patients with IB1 tumors and HPV-mRNA negative SLN status can be spared from complete lymphadenectomy and be treated by locallytailored surgery alone, whereas patients with HPVmRNA positive SLN status may profit from surgery plus lymphadenectomy and adjuvant therapy.

\section{MATERIALS AND METHODS}

\section{Study design}

This study was performed as the longitudinal, prognostic part of a, to date, largest prospective, multicenter diagnostic study which addressed the SLNconcept in cervical cancer [4]. The study protocols of the diagnostic and the prognostic part were approved by the institutional review committee of the Jena University Hospital (0175-02/00). Between March 1999 and June 2008, 338 patients with cervical cancer were eligible for enrolment (Figure 1). All patients had to be followed for at least three years or were censored as case at an earlier time point. The data base was closed on October 29, 2009. At that time 189 patients with a median follow-up period of 3.1 (range $0.5-7.8$ ) years fulfilled the study criteria. Due to the low rate of recurrent disease $(n=17)$ we decided to prolong the follow-up period. From July to November 2013 data on vital and recurrence status could be updated for 130 patients out of 172 who had no recurrence during the regular study period. Now, the median follow-up time was 8.1 (range 0.5 to 12.5 ) years. Here, we present results of our final analysis. Although initiated much earlier this study fulfils the criteria recommended for tumor marker prognostic studies (REMARK) published in 2005 [17].

\section{Patients}

Inclusion criteria were all stages of invasive cervical cancer, intention of curative surgery and complete pelvic lymphadenectomy after removal of SLN (for details see [4]). Further inclusion criteria were $\mathrm{R} 0$ resection and $\mathrm{pN} 0$ status. Preoperatively detected metastatic disease, previous lymphadenectomy, tumor-involvement of the adnexae, or neoadjuvant therapy excluded from participation. All patients who signed informed consent were enrolled consecutively.

\section{Primary endpoint and prognostic variables}

The primary endpoint was disease recurrence defined as local recurrence of primary disease, distant metastasis, death due to cervical cancer or death with unknown cause. In patients without an event observations were censored at date of last follow-up information that excluded disease recurrence. We primarily focused on the prognostic value of HPV-mRNA in pelvic SLN. HPV-mRNA-status was classified as positive, negative or probably negative. The last category was assigned to HPV-mRNA negative cases in which the SLN count by the surgeon did not match with the number counted by the pathologist. Tumor size $(\leq 20 \mathrm{~mm},>20 \mathrm{~mm}$ to $40 \mathrm{~mm}$, 
$>40 \mathrm{~mm}$ ), histology, grading and, age (post-hoc due to prolonged follow-up) were considered as additional prognostic variables.

\section{Surgery and lymph node processing}

Patients underwent complete pelvic lymphadenectomy either by laparoscopy or by open approach (for details see [4]). The pelvic area was inspected for stained/radioactive SLNs. SLNs were harvested first followed by systematic lymphadenectomy and tumor resection. Of each SLN a tissue section of $1 \mathrm{~mm}$ thickness perpendicular to the long axis of the node was taken for mRNA analysis. To avoid contamination a fresh scalpel and forceps were taken for the dissection of each individual node. The biopsy was either immediately snapfrozen in liquid nitrogen or conserved in mRNA-later for storage at $-20^{\circ} \mathrm{C}$. All lymph nodes were processed identically by the pathologists. If metastatic disease was visible macroscopically, a single section was usually sufficient to confirm disease. Normal-appearing nodes were cut perpendicular to the long axis into 3- to $4 \mathrm{~mm}$ sections and submitted for routine processing (no ultrastaging and no immunohistochemical staining). Indication for paraaortic lymphadenectomy varied between the different institutions and was given for tumor diameter larger than $3 \mathrm{~cm}$ and/or vascular space involvement and/or deep cervical stroma infiltration and/ or undifferentiated tumor (for details see [4]).

\section{HPV-genotyping of primary tumors}

HPV-genotyping was performed using genomic DNA extracted from frozen biopsy material obtained from primary tumors. Thirty-seven different genital HPV types, including all hrHPV types can be amplified by the GP5+ and GP6+bio assay [18].

\section{Detection of HPV-mRNA in sentinel lymph nodes}

\section{(i) RNA extraction and cDNA synthesis}

Approximately $30 \mathrm{mg}$ of tissue were homogenized (OMNI-TH homogenizer with dispersible tips) and total RNA was extracted thereof using the RNA Blood Mini Kit from Qiagen (Hilden, Germany) according to the manufacturer's instructions. DNase treatment was included. RNA concentration and quality were determined by spectrophotometry (NanoDrop ND-1000) and gel electrophoresis. One microgram of total RNA was reverse transcribed in a $20 \mu \mathrm{l}$ reaction comprising $20 \mathrm{pmol}$ CDSprimer $\left(5^{\prime}-\mathrm{T}_{\mathrm{n}=30} \mathrm{VN}-3^{\prime}\right), 100 \mathrm{nM}$ of each dNTP, 50mM Tris$\mathrm{HCl}(\mathrm{pH} 8.3), 75 \mathrm{mM} \mathrm{KCl}, 3 \mathrm{mM} \mathrm{MgCl} 210 \mathrm{mM}$ DTT, $20 \mathrm{U}$ RNasin und 200U SuperScriptII (GibcoBRL). To allow optimal annealing, primer and RNA were incubated at $70^{\circ} \mathrm{C}$ for $10 \mathrm{~min}$ and cooled down on ice. The remaining reagents were then added in form of a master mix and cDNA synthesis was done at $42^{\circ} \mathrm{C}$ for one hour. The reaction was stopped at $70^{\circ} \mathrm{C}$ for 15 minutes and stored at $-80^{\circ} \mathrm{C}$ until PCR analyses.

\section{(ii) qualitative detection of viral transcripts by nested} PCR (RT-nested-PCR)

For the detection of hrHPV-E6-E7 specific cDNA a nested-PCR protocol was used. By this approach one tumor cell (HPV16 positive cell line $\mathrm{SiHa}$ ) can be detected in a background of $10^{6} \mathrm{HPV}$-negative cells. All primers are located in the E6 and E7 ORFs of the viral genome and detect spliced as well as unspliced early promoter-derived oncogene transcripts. Being polycistronic, these transcripts also encode the viral oncoprotein E7 [19]. Outer and inner primers of all $13 \mathrm{hrHPV}$ types are given in Supplementary Table S1. The first PCR comprised $2 \mu \mathrm{l}$ of the cDNA reaction (equivalent to $100 \mathrm{ng} \mathrm{RNA}$ ), $50 \mathrm{mM} \mathrm{KCl}, 10 \mathrm{mM}$ Tris- $\mathrm{HCl}\left(\mathrm{pH} 8.3\right.$ ), 3.5mM $\mathrm{MgCl}_{2}, 5 \%$ DMSO, $0.2 \mathrm{mM}$ of each dNTP, 20pmol of each primer und 1.25U AmpliTaq in an end volume of $50 \mu \mathrm{l}$. After an initial denaturation step for 1 minute at $94^{\circ} \mathrm{C}, 40$ cycles of 15 seconds at $94^{\circ} \mathrm{C}, 30$ seconds at $54^{\circ} \mathrm{C}$ and 90 seconds at $72^{\circ} \mathrm{C}$ were performed. The final elongation step was prolonged by 4 minutes. For the second (nested) PCR, $2 \mu$ of the first reaction (1:3 dilution in $\mathrm{H}_{2} \mathrm{O}$ ) was used. The reaction conditions were the same as for the first PCR except for the use of inner primers. All reactions were run in a Mastercycler Gradient (Eppendorf, Hamburg, Germany). PCR products were separated in $1.2 \%$ agarose gels for Southern blot analysis. Specificity was confirmed by hybridization using internal oligonucleotide probes (Supplementary Table S1).

To control for successful reverse transcription $1 \mu 1$ of cDNA (equivalent of 50ng total RNA) was taken for the amplification of GAPDH. The primers for GAPDH were: GGTGAAGGTCGGAGTCAACG (forward) and CAAAGTTGTCATGGATGACC (reverse). Reaction conditions were as for hrHPV-E6-E7 amplification but not in the nested format. Successful amplification was assessed in agarose gels.

(iii) quantitative detection of viral transcripts by realtime PCR

Beside RT-nested-PCR which provides a highly sensitive but only a qualitative readout, we also performed quantitative real-time analysis (qRT-PCR) for a subset of SLN $(n=77)$. This assay was described in detail by Häfner and colleagues (16). Target gene expression measured in duplicate was normalized to the geometric mean of the expression of the two most stable housekeeping genes in lymph nodes (HPRT, GAPDH). 


\section{Statistical analysis}

Sample size was calculated according to the rule of ten events per variable for proportional hazards regression analysis [20]. Beside a power calculation for detection of a specified size effect, the rule of ten events per variable is used in settings were the primary focus is directed at the estimation of the marker effect after adjustment for a set of standard variables as rationale for sample size [21]. We used this rule as a pragmatic sample size justification for the following reasons: First, our prognostic study was performed in a subgroup of patients participating in our prospective, multicenter diagnostic study which addressed the sentinel lymph node concept in cervical cancer. The total sample size, which was previously calculated according to the objective of the diagnostic study, restricted the number of eligible patients for the prognostic part. Second, due to the early phase of marker evaluation we focused on estimating the independent marker effect after adjustment for a set of pre-defined variables rather than significance testing. Taking into account five independent variables 50 patients with recurrence and 334 overall would be required for analysis assuming a recurrence rate of $15 \%$ within three years. Median follow-up time was calculated by the reverse Kaplan-Meier method [22]. Kaplan-Meier curves were generated to display recurrence-free survival and to estimate 5 -years rates with $95 \%$ confidence intervals (CI). Strength of association between prognostic variables and recurrence-free survival was quantified by crude and adjusted hazard ratios (HR) from Cox regression models with $95 \%$ CI. The population for the primary analyses comprised only patients with unequivocal HPV-mRNA findings. For sensitivity analyses we assigned patients with probably negative HPV-mRNA status to the HPVmRNA-negative group. We analyzed overall survival as a post-hoc specified endpoint in a similar way. Statistical comparisons were made by t-test, $\mathrm{Chi}^{2}$ test, $\log$ rank test and Wald test as appropriate. For comparison of laboratory methods the kappa statistic was calculated. The two-sided level of significance was 0.05 . All data were managed in an ACCESS database and were analyzed with statistical software SAS 9.3 and Stata 12.0.

\section{ACKNOWLEDGMENTS}

We thank Bernhard Müller for RNA analysis at the initial stage of the study and Jana Ziegler, Christiane Dietrich and Antje Brandstädt for supporting data management and analysis.

\section{CONFLICTS OF INTEREST}

All authors declare that they have no financial or other interest that is relevant to the subject matter under consideration in this article.

\section{GRANT SUPPORT}

This study was funded by the German Cancer Aid (Uterus 3 der AGO, grant number 70-3008-Schn5).

\section{Editorial note}

This paper has been accepted based in part on peerreview conducted by another journal and the authors' response and revisions as well as expedited peer-review in Oncotarget.

\section{Authors' contributions}

Concept and design: $\mathrm{MD}, \mathrm{HH}$ and $\mathrm{AS}$

Provision of study materials or patients: CA, UM, PH, TD, ML, KUP IBR and AS

Collection and assembly of data: All authors

Data analysis and interpretation: MD, HH, NH, IBR and AS

Manuscript writing: All authors

Final approval of manuscript: All authors

\section{REFERENCES}

1. Delgado G, Bundy BN, Fowler WC, Jr., Stehman FB, Sevin B, Creasman WT, Major F, DiSaia P and Zaino R. A prospective surgical pathological study of stage I squamous carcinoma of the cervix: a Gynecologic Oncology Group Study. Gynecologic oncology. 1989; 35:314-320.

2. Look KY, Brunetto VL, Clarke-Pearson DL, Averette HE, Major FJ, Alvarez RD, Homesley HD and Zaino RJ. An analysis of cell type in patients with surgically staged stage IB carcinoma of the cervix: a Gynecologic Oncology Group study. Gynecologic oncology. 1996; 63:304-311.

3. Morton DL, Wen DR, Wong JH, Economou JS, Cagle LA, Storm FK, Foshag LJ and Cochran AJ. Technical details of intraoperative lymphatic mapping for early stage melanoma. Arch Surg. 1992; 127:392-399.

4. Altgassen C, Hertel H, Brandstadt A, Kohler C, Durst M, Schneider A and Group AGOS. Multicenter validation study of the sentinel lymph node concept in cervical cancer: AGO Study Group. J Clin Oncol. 2008; 26:2943-2951.

5. Darlin L, Persson J, Bossmar T, Lindahl B, Kannisto P, Masback A and Borgfeldt $\mathrm{C}$. The sentinel node concept in early cervical cancer performs well in tumors smaller than $2 \mathrm{~cm}$. Gynecologic oncology. 2010; 117:266-269.

6. Cibula D, Abu-Rustum NR, Dusek L, Slama J, Zikan M, Zaal A, Sevcik L, Kenter G, Querleu D, Jach R, Bats AS, Dyduch G, Graf P, Klat J, Meijer CJ, Mery E, et al. Bilateral ultrastaging of sentinel lymph node in cervical cancer: Lowering the false-negative rate and improving the 
detection of micrometastasis. Gynecologic oncology. 2012; 127:462-466.

7. Lecuru F, Mathevet P, Querleu D, Leblanc E, Morice P, Darai E, Marret H, Magaud L, Gillaizeau F, Chatellier G and Dargent D. Bilateral negative sentinel nodes accurately predict absence of lymph node metastasis in early cervical cancer: results of the SENTICOL study. J Clin Oncol. 2011; 29:1686-1691.

8. Gortzak-Uzan L, Jimenez W, Nofech-Mozes S, Ismiil N, Khalifa MA, Dube V, Rosen B, Murphy J, Laframboise $\mathrm{S}$ and Covens A. Sentinel lymph node biopsy vs. pelvic lymphadenectomy in early stage cervical cancer: is it time to change the gold standard? Gynecologic oncology. 2010; 116:28-32.

9. Schwartz GF, Giuliano AE, Veronesi U and Consensus Conference C. Proceedings of the consensus conference on the role of sentinel lymph node biopsy in carcinoma of the breast, April 19-22, 2001, Philadelphia, Pennsylvania. Cancer. 2002; 94:2542-2551.

10. Horn LC, Hentschel B, Fischer U, Peter D and Bilek K. Detection of micrometastases in pelvic lymph nodes in patients with carcinoma of the cervix uteri using step sectioning: Frequency, topographic distribution and prognostic impact. Gynecologic oncology. 2008; 111:276281.

11. Bostick PJ, Chatterjee S, Chi DD, Huynh KT, Giuliano AE, Cote R and Hoon DS. Limitations of specific reversetranscriptase polymerase chain reaction markers in the detection of metastases in the lymph nodes and blood of breast cancer patients. J Clin Oncol. 1998; 16:2632-2640.

12. Van Trappen PO, Gyselman VG, Lowe DG, Ryan A, Oram DH, Bosze P, Weekes AR, Shepherd JH, Dorudi S, Bustin SA and Jacobs IJ. Molecular quantification and mapping of lymph-node micrometastases in cervical cancer. Lancet. 2001; 357:15-20.

13. Bleiweiss IJ, Nagi CS and Jaffer S. Axillary sentinel lymph nodes can be falsely positive due to iatrogenic displacement and transport of benign epithelial cells in patients with breast carcinoma. J Clin Oncol. 2006; 24:2013-2018.

14. Walboomers JM, Jacobs MV, Manos MM, Bosch FX, Kummer JA, Shah KV, Snijders PJ, Peto J, Meijer CJ and Munoz N. Human papillomavirus is a necessary cause of invasive cervical cancer worldwide. The Journal of pathology. 1999; 189:12-19.

15. Häfner N, Driesch C, Gajda M, Jansen L, Kirchmayr R, Runnebaum IB and Dürst M. Integration of the HPV16 genome does not invariably result in high levels of viral oncogene transcripts. Oncogene. 2008; 27:1610-1617.

16. Häfner N, Gajda M, Altgassen C, Hertel H, Greinke C, Hillemanns P, Schneider A and Dürst M. HPV16-E6 mRNA is superior to cytokeratin $19 \mathrm{mRNA}$ as a molecular marker for the detection of disseminated tumour cells in sentinel lymph nodes of patients with cervical cancer by quantitative reverse-transcription PCR. Int J Cancer. 2007; 120:1842-1846.
17. McShane LM, Altman DG, Sauerbrei W, Taube SE, Gion M, Clark GM and Statistics Subcommittee of the NCIEWGoCD. Reporting recommendations for tumor marker prognostic studies (REMARK). Journal of the National Cancer Institute. 2005; 97:1180-1184.

18. Jacobs MV, Snijders PJ, van den Brule AJ, Helmerhorst TJ, Meijer CJ and Walboomers JM. A general primer GP5+/ GP6(+)-mediated PCR-enzyme immunoassay method for rapid detection of 14 high-risk and 6 low-risk human papillomavirus genotypes in cervical scrapings. Journal of clinical microbiology. 1997; 35:791-795.

19. Zheng ZM and Baker CC. Papillomavirus genome structure, expression, and post-transcriptional regulation. Frontiers in bioscience : a journal and virtual library. 2006; 11:22862302.

20. Peduzzi P, Concato J, Feinstein AR and Holford TR. Importance of events per independent variable in proportional hazards regression analysis. II. Accuracy and precision of regression estimates. Journal of clinical epidemiology. 1995; 48:1503-1510.

21. Altman DG, McShane LM, Sauerbrei W and Taube SE. Reporting Recommendations for Tumor Marker Prognostic Studies (REMARK): explanation and elaboration. PLoS medicine. 2012; 9:e1001216.

22. Schemper M and Smith TL. A note on quantifying followup in studies of failure time. Controlled clinical trials. 1996; 17:343-346.

23. Euscher ED, Malpica A, Atkinson EN, Levenback CF, Frumovitz M and Deavers MT. Ultrastaging improves detection of metastases in sentinel lymph nodes of uterine cervix squamous cell carcinoma. The American journal of surgical pathology. 2008; 32:1336-1343.

24. Patani $\mathrm{N}$ and Mokbel K. Clinical significance of sentinel lymph node isolated tumour cells in breast cancer. Breast cancer research and treatment. 2011; 127:325-334.

25. Morton DL, Hoon DS, Cochran AJ, Turner RR, Essner R, Takeuchi H, Wanek LA, Glass E, Foshag LJ, Hsueh EC, Bilchik AJ, Elashoff D and Elashoff R. Lymphatic mapping and sentinel lymphadenectomy for early-stage melanoma: therapeutic utility and implications of nodal microanatomy and molecular staging for improving the accuracy of detection of nodal micrometastases. Annals of surgery. 2003; 238:538-549; discussion 549-550. 